\title{
The Architecture Behind the Malpractice Concept Guidelines
}

\author{
Safa Singrid Adriana Canbolant \\ “Dimitrie Cantemir” Christian University, Bucharest, Romania, canbolantsingrid.khc@gmail.com
}

\begin{abstract}
The right to life is a goal written in many written and unwritten norms, and alongside it, we can align the responsibility and, at the same time, the liability of those who have the duty to perform the medical act with holiness and dedication. Starting from common law, imperative norms and devices and going beyond the universal right, like for example, the one built up by the European Convention on Human Rights, we can unequivocally affirm that the right to life, health and the integrity of the individual is the most important human right, which not only the state has to protect, but every one of us. Thus, through this study, we will try to substantiate the pillars of ethics that medical art has woven its way through the passage of time, pointing to another essential goal - to prevent malpractice.
\end{abstract}

KEYWORDS: Code of Ethics, ethics, health, law, malpractice

\section{Introduction}

The concept of malpractice has appeared since the earliest times, since 1725 before our time (Bioclima n.d.). Thus, among the first provisions on criminal and civil liability, appears in the "Code of Hammurabi," "The laws of Manu," "The Books of Life," "Vedels (India)." Moreover, the doctor's conditions of activity and his liability for mistakes made, appear in biblical books.

Going into the philosophical field, we can remember that Plato was the one who claimed that the doctor had professional immunity, and Aristotle, on the other hand, stated that the judge should understand if the actions were made as a result of constraint or ignorance, and that collective justice will apply to any type of relationships, both civil and criminal (Mangu 2010).

\section{Defining the term malpractice. Legal regulation}

According to Article 642 of Law no 95/2006 on healthcare reform, malpractice is the professional misconduct committed in the exercise of the medical or medical-pharmaceutical act, generating damages to the patient, involving the civil liability of the medical staff and the provider of medical, sanitary and pharmaceutical products and services (Law no 95/2006 on Health Reform, as subsequently amended and supplemented, published in the Official Gazette no 372/28 April 2006).

By the idea of medical staff, we refer to doctor, dentist, pharmacist, nurse and midwife who provides medical services. They contribute to the observance of the fundamental human rights enshrined in Art. 22 of the Romanian Constitution, namely the right to life and the right to physical and mental integrity.

Considering the importance and the multitude of these errors at the present time, at the level of the public health departments have been set up certain committees that deal with monitoring and professional competence in cases of malpractice that are perceived by injured persons. An important aspect is that these institutions are not in charge to deal with the prevention area, but they are in charge with establishing the competence and the responsible medical framework, rather than the prevention of such acts.

Following a thorough study, it has been concluded that issues such as sanctioning or preventing malpractice acts are, at a weaker level, the Commission of malpractice itself having unclear attributions that often overlap with those of other law enforcement agencies. Because of this, we are constantly working on a way of systematizing and maximizing these institutions, in order to be able to significantly reduce any kind of medical error that ends with the physical or mental injury of a person. 


\section{The Code of Medical Deontology}

Since ancient times, medicine aims to protect human health by completing the disciplines that guarantee freedom of expression and affirmation, these being represented by legal and ethical sciences.

The Code of Medical Deontology contains rules of conduct with mandatory character, which refers to the exercise of the rights and duties of a doctor as a professional.

Article 3 of the present Code enshrines the health of the individual as a superior goal, the medical staff and, in particular, the doctor having the obligation to protect the health of the patients and their dignity regardless their age, gender, race, ethnicity, nationality, religion and political ideologies.

As for the violation of these rules, the doctor may be held accountable if the guilty conduct of that person has resulted in injury to the individual.

Ethics, morals and deontology are the elements that form the main ethical and deontological aspects of medical activity. The term ethics (ethos $=$ manners) studies moral categories and principles, rules of conduct, etc.

Through morality, it is reflected how ethical principles are applied in everyday life that can be defined as the science of human well-being and responsability. Regarding the deontology (deon $=$ what it is needed, $\operatorname{logos}=$ science), it studies the obligations and regulations of professional activity, including one of the doctors. That is why knowledge of these bases is an essential condition for eliminating the negative sides of medical activity, and this profession cannot be conceived without respecting the principles of ethics and deontology.

Speaking of the basic principles of exercising the profession of doctor, as they are inscribed in the code, we observe:

The purpose and role of the medical profession (defending the individual's life, health, physical and mental integrity)

- Respecting the dignity of the human being

- Non-discrimination

- Obligation of professional rules (all diligences, rules and professionals obligations, as well as those relating to conduct)

- Professional independence (it is forbidden to determine the medical act for economic or administrative reasons)

- The primordial interest of the human being

- Obligation of diligence by means (the entire doctor's knowledge and skill is dedicated to the patient, who has a guarantee of the decisions made by the medical staff)

- Professional specialization (the doctor acts according to its specialty)

- Doctor-patient relationship (exclusively professional)

\section{The insurance for malpractice}

The concept of civil liability within this area aims to compensate for damage caused by an unlawful act. As for the medical act, although it does not definitively exclude the commission of an illicit deed intentionally, however, we often deal with acts of guilt, in the doctrine being presented several types of fault, such as:

1. Omission guilt (inaction)

2. Comisiv quilt ((imprudence, incomprehension)

3. Culpa in vigilando (uninformation)

4. Culpa in eligendo (wrong choice of medical procedures)

Another crucial aspect that led to the necessity of such insurance is the distinction between the mistake of failure to comply with the norms of medical behavior and the mistake of medical error that is determined by various critical situations, in most cases regardless of good-faith and conscientiousness of the medical frame. 
According to the Article 656 of the Law no 95/2006, the medical staff who provide healthcare, both in the public and private system, in a special destination for medical care, as well as when it is given outside this place, following an express request from the person or those requiring this assistance, or a third person requesting it.

The insurance for medical malpractice is mandatory, all of which are members of the medical staff being obliged to take out civil professional liability insurance, the copy of which must be submitted before the conclusion of the employment contract.

Speaking of the parties to the medical malpractice insurance contract, the essential condition is to be retained, namely to be part of the medical staff category. Better said, the insured person must have one of the following professions: doctor, dentist, nurse, pharmacist, midwife etc.

Table 1. Comparison between the original and current version of the Hippocrates Oath

\begin{tabular}{|c|c|}
\hline Original version & Current version \\
\hline $\begin{array}{l}\text { I swear to Apollo the doctor, Higea and Panacea, } \\
\text { and all the gods and goddesses, whom I take as } \\
\text { witnesses, that I will do this oath and his } \\
\text { commandments as much as the forces and reason } \\
\text { help me. }\end{array}$ & I make this oath solemnly, free, of honor! \\
\hline $\begin{array}{l}\text { To respect the one who taught me this art just like } \\
\text { my own parents, to share with him what belongs } \\
\text { to me and take care of him when he needs, to } \\
\text { consider his descendants as brothers and to teach } \\
\text { them art, if they want it, without obligation and } \\
\text { without being paid. }\end{array}$ & $\begin{array}{l}\text { I will keep my teachers the respect and } \\
\text { recognition which are due to them. }\end{array}$ \\
\hline $\begin{array}{l}\text { To pass on the teachings of this art to my sons, to } \\
\text { my master's sons, and to those disciples who } \\
\text { swore by doctor's habit and nobody else. }\end{array}$ & \\
\hline $\begin{array}{l}\text { Sacred and clean I will keep my art and lead my } \\
\text { life. }\end{array}$ & $\begin{array}{l}\text { I solemnly commit to devoting my life to serving } \\
\text { the community. }\end{array}$ \\
\hline $\begin{array}{l}\text { As much as the forces and reason help me, my } \\
\text { perseverance is made only for the benefit and } \\
\text { good condition of the sick, to guard them against } \\
\text { any harm or violence. }\end{array}$ & $\begin{array}{l}\text { The health of patients will be for me the sacred } \\
\text { obligation. }\end{array}$ \\
\hline $\begin{array}{l}\text { I will never prescribe a substance with moral } \\
\text { effects, even if I am asked for it, and I will not } \\
\text { give any advice in this regard. I will never give an } \\
\text { avortiv remedy to a woman. }\end{array}$ & \\
\hline $\begin{array}{l}\text { Whatever I see or hear during a treatment will be } \\
\text { kept in secret, because silence is a duty. }\end{array}$ & $\begin{array}{l}\text { I will keep the secrets entrusted by the patient } \\
\text { even after their death. }\end{array}$ \\
\hline \multirow[t]{2}{*}{$\begin{array}{l}\text { If I respect this oath and I will not tread it, my life } \\
\text { and my art will enjoy reputation and respect from } \\
\text { all people, if I betray it by perjury, then the } \\
\text { opposite. }\end{array}$} & $\begin{array}{l}\text { I will keep full respect for human life from its } \\
\text { beginnings even under threat and will not use my } \\
\text { medical knowledge contrary to the laws of } \\
\text { humanity. }\end{array}$ \\
\hline & $\begin{array}{l}\text { I will not allow to interfere between my duty and } \\
\text { the patient considered by nationality, race, } \\
\text { religion, party or social status. }\end{array}$ \\
\hline
\end{tabular}

Source: Dancea 2015

The insurance remains valid for the whole period of the medical profession, ending with the loss of the quality of being part of the medical staff category. 


\section{Duties}

As we know, every doctor needs specialized training, and this tortuous road ends with the submission of a sacred oath that has its origins since ancient times

So, among the duties of medical staff, can be reminded:

1. To inform the patient about treatment and its real situation

2. To be up to date with medical advances

3. Keep professional secrecy

4. To respect the dignity of the patient, and other aspects of the oath filed.

\section{Malpractice analysis}

The term of malpractice defines the same issue, both nationally and internationally. However, we have tried to make a comparison of this concept.

Table 2. Brief comparison regarding the malpraxis in the world

\begin{tabular}{|c|c|c|}
\hline Romania & Europe & World \\
\hline $\begin{array}{l}\text { Law no } 95 / 2006 \text { on health } \\
\text { reform. }\end{array}$ & $\begin{array}{l}\text { Germany, France and the UK } \\
\text { have regulations to control } \\
\text { malpractice. }\end{array}$ & $\begin{array}{l}\text { US-Office of Research } \\
\text { Integrity controls reports of } \\
\text { scientific malpractice from } \\
\text { sustained research through } \\
\text { US Public Health Service. }\end{array}$ \\
\hline & $\begin{array}{l}\text { In Spain, for example, most } \\
\text { research institutions do not } \\
\text { have scientific integrity codes } \\
\text { or policies to address } \\
\text { malpractice. }\end{array}$ & \\
\hline $\begin{array}{l}\text { The patient, in the case of } \\
\text { malpractice, may address } \\
\text { either to the police or to the } \\
\text { court. } \\
\text { In addition, you can opt for a } \\
\text { prior mediation procedure. }\end{array}$ & $\begin{array}{l}\text { In the absence of appropriate } \\
\text { customs, internal regulations } \\
\text { can provide solutions through } \\
\text { conciliation or arbitration, as } \\
\text { is the case in Deutsche } \\
\text { Forschungsgemeinschaft. }\end{array}$ & $\begin{array}{l}\text { In countries like China, } \\
\text { Indonesia, Vietnam, or } \\
\text { Thailand, patients who } \\
\text { consider themselves injured } \\
\text { appeals to the hospital for the } \\
\text { payment of damages. }\end{array}$ \\
\hline
\end{tabular}

\section{Malpractice internally}

Internally, we can affirm that there have been numerous cases, more than 1850 complaints of malpractice have been brought in the last 10 years to the attention of the county colleges of doctors.

The death and medical malpractice have been added in recent years to the thick list of reasons why Romania is sued at the CEDO (Corlățean 2011) and even convicted by the Strasbourg Court (cases: Cojocaru, Mihu Romila, etc.).

Nevertheless, an improvement in the precarious situation of the Romanian medical system is being attempted. Until now, we cannot pronounce on some controversial issues, but with a fair analysis, new and new recommendations can be made.

Ever since joining the European Union, Romania had an obligation to adopt a legislation to stipulate medical malpractice, which has led to a reduction in the number of cases in which medical staff are guilty (Călin 2016).

\section{Malpractice internationally}

In most European countries, the legislation does not address cases of malpractice, but we can see that some countries have found innovative tools and methods to improve things (Ibidem). For example, public health is one of the areas where the European Union has only support competences, meaning that its action merely complements the actions of the member states. In addition, the 
organization of health services in the European Union is primarily a national competence of the member states, which are free to organize their health systems, to make decisions on how the system works and its finances.

\section{Conclusions}

Therefore, the interweaving of responsibility and liability has a fundamental role in the development of a society regarding the malpractice, and beyond identifying the culprits, whether we are talking about the fault of the hospital, the doctor or even the patient, prevention is perhaps the most important aspect.

Health occupies a primordial place in our lives. The European Union plays an important role, supporting national governments in their efforts to maintain during our lives. That is why we need to make more efficient use of resources that can prove to be valuable in improving the health of the population and maintaining the efficiency and sustainability of the health system will grow (Vlădescu and Buşoi 2011).

Therefore, increased attention should be paid to preventing and promoting a healthy, longer and more active life by addressing life-cycle health determinants.

\section{References}

Bioclima. n.d. What we know and what we do not know about malpractice. Available at http://bioclima.ro/164CNB.pdf. Călin, Roxana Maria. 2016. Malpractice. Liability of medical personnel and healthcare provider. Judicial practice. $2^{\text {nd }}$ Edition. Bucharest: Hamangiu Publishing House.

Corlățean, Titus. 2011. Enforcement of judgments of the European Court of Human Rights. Bucharest: Universul Juridic Publishing House.

Dancea, Dani. 2015. "The Hippocratic Oath of the Graduates of Medicine. As the doctors swears, 'on all gods and goddesses' that they will be good doctors." Adevarul.ro. Available at https://adevarul.ro/locale/timisoara/traditiablasfemica-inca-respectata-medicina-jura-absolventii-pe-zeii-zeitele-vor-doctori-buni-1_564e30ab7d919ed50 e62a4b2/index.html.

Grazer, Brian, and Charles Fishman. 2015. A Curious Mind: The Secret to a Bigger Life. New York: Simon \& Schuster. Law no 95/2006 on Health Reform, as subsequently amended and supplemented, published in the Official Gazette no 372/28 April 2006, http://www.cdep.ro/pls/legis/legis_pck.htp_act_text?idt=72105.

Mangu, Florin. 2010. Medical malpractice. Medical civil liability. Bucharest: Wolters Kluwer Publishing House.

Vlădescu, Cristian, and Bușoi, Cristian. 2011. Health Policies in the European Union. Bucharest: Polirom Publishing House. 